\title{
Transatlantica
}

Revue d'études américaines. American Studies Journal

\section{Interview with Judith Gutman}

Jean Kempf

\section{(2) OpenEdition}

\section{Journals}

Electronic version

URL: https://journals.openedition.org/transatlantica/6339

DOI: 10.4000/transatlantica.6339

ISSN: $1765-2766$

\section{Publisher}

Association française d'Etudes Américaines (AFEA)

\section{Electronic reference}

Jean Kempf, "Interview with Judith Gutman", Transatlantica [Online], 1 | 2013, Online since 16 February 2014, connection on 04 February 2023. URL: http://journals.openedition.org/transatlantica/6339 ; DOI: https://doi.org/10.4000/transatlantica.6339

This text was automatically generated on 4 February 2023.

\section{(c) (i) (9)}

Creative Commons - Attribution-NonCommercial-NoDerivatives 4.0 International - CC BY-NC-ND 4.0 https://creativecommons.org/licenses/by-nc-nd/4.0/ 


\title{
Interview with Judith Gutman
}

\author{
Jean Kempf
}

1 Judith Mara Gutman est une historienne de la photographie et de la culture américaine (Is America Used Up, 1973), spécialiste de Lewis Hine sur lequel elle a écrit deux livres de référence (Lewis Hine and the American Social Conscience, 1967 et Lewis W. Hine, 1874-1940: Two Perspectives, 1974). Elle est la commissaire invitée de l'exposition "The Future of America: Lewis Hine's New Deal Photographs" qui complète la rétrospective Hine à l'ICP (voir critique).

2 Elle prépare actuellement un ouvrage sur la dernière partie de l'œuvre de Hine, présentée dans cette exposition, When Innovation was King. Lewis Hine's 1930s Photographs of America in Transition qui sera publié en 2014 chez Howard Greenberg/Steidl. Transatlantica l'a rencontrée à l'International Center of Photography le 18 octobre 2013.

JK: The photographic archive of the National Research Project (NRP) is virtually unknown, even of scholars of the period. How did you find it?

JG: After my book Lewis Hine and the American Social Conscience came out in 1967, I got a call from the head of the media division at the National Archives and he asked: "Do you know we have the Lewis Hine photographs here?" I did not. So I went to see them. I was astonished, there was a strange fascination about them, but I didn't know what to make of them. Then later, around 1974, I had another call from the media division telling me they were going to deaccession the extra prints but they could only go to an institution. I suggested the International Center of Photography, which was just starting at the time, and so they entered the ICP collection.

In 1982, I did a book and exhibition on India [Through Indian Eyes] and the Times did a long piece on it, and asked me if I wanted to do a piece on something I was working on at the moment. This is how I came to write an article for the Times in 1983 on Hine's National Research Project pictures but the piece was halfway there, as I didn't quite understand the full social context of the pictures. It got a bit of attention and Afterimage asked me for a fuller piece, which I did. Although it was better I think than the Times piece, it was still halfway there. And the next thing I know I was sitting down with Brian Wallis [ICP Chief Curator] who reminded me of the Hine 
photographs that ICP held. I then found the reports at the New York Public Library (about a dozen) and went back to the National Archives to read and look at NRP files and was told I was probably the first person to do it.

$\mathrm{JK}$ : What size is this archive?

JG: There are two individually filed archives, one of the NRP's verbal records. That is approximately 50 standard Archive boxes. Separately filed are 800 photographs. I don't know about the negatives because Hine used to do the printing at his home, his decision.

JK: Now, let's talk about the exhibition itself.

JG: At some point the idea of a Hine exhibit materialized. I and Brian [Wallis] built the idea of an exhibit around their holding of the Hine pictures.

JK: How were the pictures selected?

JG: I was given a certain amount of space and the selection is entirely mine. So I had about 35 to 40 pictures to choose from the collection held by ICP. I wrote the text, and I insisted on a large introductory text because people have to know about the context.

\section{JK: How did those images change your reading of Hine?}

JG: The NRP was the first time when Hine could really marry the various aspects of his previous work. Here in the NRP he manages to combine philosophically all his previous interests. He actually wrote to Paul Kellogg that it was more "worthwhile" than anything he had done before (Paul Kellog was the one who suggested Hine to David Weintraub, the NRP Project director). Well, that's a big statement, which is more than just the flush of the moment. You can see it in his notes, the details with which he talks about the machinery is overwhelming. He was so excited about what he was working on.

The whole notion of man and machine is actually his. In fact, it's Man (used generically) in Action. His training was in sociology and social work. His mind was already there even before he took pictures.

But the real backbone of the project is the idea of innovation. I see this as a theme endemic to the 1930s. Depression in fact stimulated innovation as is said in one of the reports. I don't simply mean technical innovation, but more a sense of "the world's open, let's do it!", trying what had not been tried before, "Let's venture!" giving to everything a sense of adventure. Nobody accepted failure. They knew they could do it. And you see it also in all sorts of art forms and publications.

Even the way this NRP project was organized. There were 400 people, (clerks editors and investigators) in the project and Weintraub gave them free rein. Even the language of the executive order [Executive Order 7034] creating the WPA in March 1935 bore that mark. Innovation is a theme which runs through the whole New Deal. And that's what makes those images very different from the FSA photographs. And that is what my book [When Innovation was King] will be.

JK: Talking about innovation, there's the place of unions in society which was very innovative in the New Deal. Do you see any of that in Hine's pictures?

JG: Not in the work. In the reports yes, but not in the pictures. He had never shown any interest in that earlier either. Actually I have the impression that was because Hine was more interested in the relationship with people, between people, people in 
their workplace. He was basically a people's person. Because he had conversation with other people he went into the workplaces assuming that the people had a new relationship and that was what he photographed.

JK: One of the recurring questions in the historiography of the period is why didn't he join the FSA.

JG: He wanted to but [Roy] Stryker [head of the FSA photo unit] didn't want him to. I remember Stryker writing somewhere that Hine was too much of an artist. Hine always wanted the recognition of art. In the 1920s he wrote to Paul Kellogg on the occasion of an exhibition of his pictures that he was really miffed not to be recognized as an artist. He was very conscious of producing artful photographs and the NRP project was the first time when he could do that, spurred by the decade's innovation and the Project's substantive matter.

In the Empire State he was still emulating the heroic male, whereas in these pictures it's the very relationship of the worker with the machine, which is central. You can see it in the way the people look at the machines or even into the machines (the boiler maker one for instance). And this comes out powerfully in his very careful and subtle compositions.

\section{JK: How would you define Lewis Hine's place in the history of photography?}

JG: First I'd say that the black-and-white range of those photographs is mindful of what Ansel Adams would three years later call the zone system.

Then the lesson for photography is that the more a photographer is truly involved in substantive material the more he's going to naturally develop, innovate, intensify, expand, all those words; and I think Hine did that. By substantive I mean things that affect society, not "significance" which has become a pat phrase. Weintraub gave him license. On the back of every photograph there's a stamp saying "Not to be used before January 1938" and that was to give Hine a chance to use them himself.

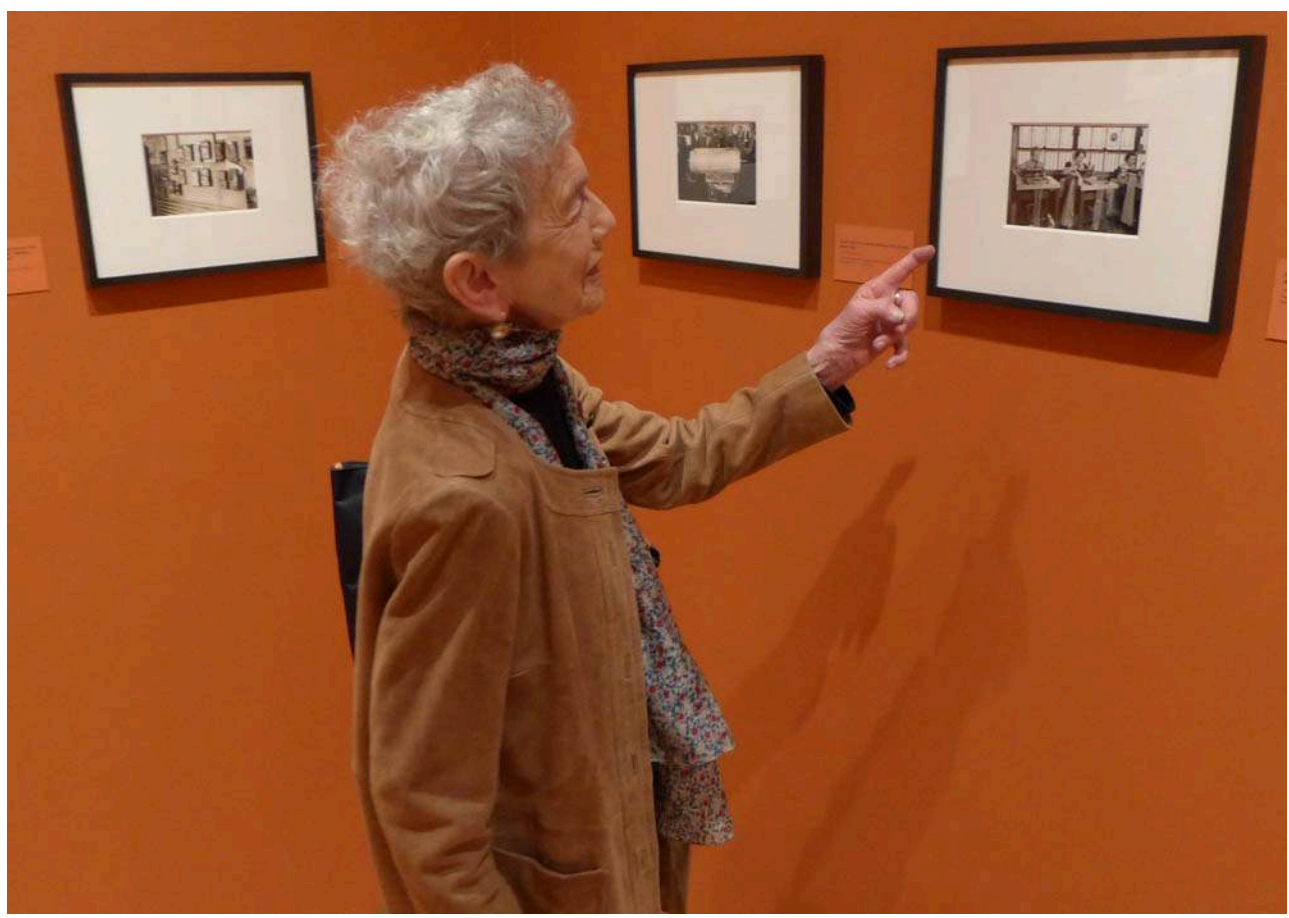

(C) Jean Kempf 


\section{BIBLIOGRAPHY}

GUTMAN, Judith Mara, Is America Used Up, New York, Grossman Publishers, 1973.

---, Lewis Hine and the American Social Conscience, New York, Walker, 1967.

---, Lewis W. Hine, 1874-1940 : Two Perspectives, New York, Grossman Publishers, 1974.

---, Through Indian Eyes, New York, Oxford University Press, 1982.

---, When Innovation was King. Lewis Hine's 1930s Photographs of America in Transition, Howard Greenberg/Steidl, à paraître en 2014.

INDEX

Subjects: Trans'Arts

\section{AUTHOR}

\section{JEAN KEMPF}

Université Lumière Lyon 2 